\title{
SPIS RZECZY POZOSTAEYCH PO ŚMIERCI AUGUSTYNA JAKUBA DZIALYŃSKIEGO, WOJEWODY KALISKIEGO Z DNIA 5 CZERWCA 1759 ROKU
}

DOI: http://dx.doi.org/10.12775/SPLP.2021.004

\section{Streszczenie}

W Bibliotece Kórnickiej Polskiej Akademii Nauk znajdują się zbiory rękopisów związanych $\mathrm{z}$ historią rodziny Działyńskich. W jednym z takich zbiorów znajduje się dokument powstały w związku ze śmiercią Augustyna Działyńskiego (13 V 1759), wojewody kaliskiego - spis pozostawionych przez niego rzeczy. Ze spisu, datowanego na 5 czerwca 1759 roku, dowiadujemy się o jego ubiorze, ubiorze służby, rzeczach codziennego użytku, o ozdobach pomieszczeń, o instrumentach muzycznych i posiadanym ekwipunku jeździeckim. Ozdobienie większości tych rzeczy w srebro lub złoto, świadczy o stanie posiadania osoby zmarłej. Do spisu dołączono także wykaz zobowiązań wojewody oraz wysokość kosztów poniesionych w związku z jego pogrzebem. Artykuł uzupełniają portrety Augusta Działyńskiego i jego żony Anny z Radomickich oraz bogaty materiał genealogiczny.

Słowa kluczowe: Działyński, genealogia, inwentarz, ruchomości 


\author{
THE POST-MORTEM INVENTORY \\ OF AUGUSTYN JAKUB DZIAEYŃSKI, \\ A VOIEVOD OF KALISZ FROM 5 JUNE 1759
}

\begin{abstract}
The Kórnik Library of the Polish Academy of Sciences houses a large collection of manuscripts related to the history of the Działyński family. One of those collections contains a document created after the death of Augustyn Działyński (13 May 1759), a voievod of Kalisz, i.e. a post-mortem inventory. The inventory dated 5 June 1759 includes information on his attire, the garb of his servants, things of everyday use, decorations of his chambers, musical instruments and his horseriding equipment. Most of these items were decorated with gold or silver which shows the wealth of the deceased. The inventory is complemented with a list of Działyński's liabilities and the funeral expenditure. The paper is illustrated with portraits of Augustyn Działyński and his wife Anna nèe Radomicka as well as with extensive genealogical data.
\end{abstract}

Keywords: Działyński, genealogy, inventory, movables

W Bibliotece Kórnickiej Państwowej Akademii Nauk, w zbiorze rękopisów, znajdują się dokumenty dotyczące Augustyna Działyńskiego. W jednym ze zbiorów, sygn. BK 07235, znajduje się sporządzony po jego śmierci, przez jego żonę Annę z Radomickich, spis pozostawionych przez zmarłego ruchomości. Spis ten jest datowany na 5 czerwca 1759 roku. Dokonywanie spisów pozostawionych przez zmarłych ruchomości był w XVII i XVIII wieku powszechną metodą dla zabezpieczenia wszelkich roszczeń spadkobierców. Dokument ten wraz z testamentem, o ile został taki sporządzony, stanowił podstawę podziału majątku. Niekiedy był sporządzany wraz z oszacowaniem wartości spisywanych rzeczy. $\mathrm{O}$ ile testament był często uwierzytelniany w księgach grodzkich ${ }^{1}$ lub miejskich w przypadku mieszczan, tak spisy pozostawały w rękach spadkobierców. Spora ilość tego typu dokumentów pozostaje w tzw. aktach podworskich, nie tak często przeglądanych, jak wszelkie księgi grodzkie, ziemskie czy miejskie.

Spisy ruchomości dają szerokie możliwości do prac badawczych dla poznania różnych aspektów życia w Polsce z okresu nowożytnego. Stanowią bogaty materiał o sprzęcie domowym i gospodarczym, ubiorze, wyposażeniu w broń, rzeczy

Na ogół inwentarze uwierzytelniano w ciągu jednego roku (79 proc.), zob. A. Pośpiech, Pułapka oczywistości. Pośmiertne spisy ruchomości szlachty wielkopolskiej z XVII wieku, Letter Quality, Warszawa 1992, s. 70. 
codziennego użytku zróżnicowane od posiadanego bogactwa, czy też rzeczy związane z osprzętem dla koni. Temat ten, jako edycja źródeł historycznych, doczekał się wielu opracowań, dotyczących pojedynczych spisów, często dołączanych do testamentów, natomiast brak jest opracowań zbiorczych ${ }^{2}$. Inwentarze (spisy) są trudne w edycji ze względu na stosowany język, wyrazy, które wyszły z użycia, wtrącenia obcojęzyczne lub dziwne sformułowania językowe.

Augustyn Jakub Działyński h. Ogończyk był pierwszym dzieckiem Józefa ${ }^{3}$ i Marianny Katarzyny z Potulickich ${ }^{4}$. Ślub jego rodziców miał miejsce w Lubiszewie 2 listopada 1714 roku $^{5}$. Augustyn urodził się w Kościelcu 28 sierpnia 1715 roku, ochrzczony został w tamtejszym kościele w dniu 31 sierpnia przez prebendarza kościeleckiego Marcina Leśnickiego. Chrzestnymi jego byli: Franciszek Zborowski i pani Pruchnicka ${ }^{6}$. Posiadał rodzeństwo:

- Marcina Andrzeja, urodzonego na zamku w Więcborku 14 listopada 1716 roku ${ }^{7}$, zmarłego w Lejda (Holandia) 15 września 1746 roku $^{8}$,

- Adama Stanisława, urodzonego 7 maja 1718 roku, który zmarł po chrzcie i został pochowany w kościele farnym w Złotowie ${ }^{9}$,

- Magdalenę Małgorzatę, urodzoną w Złotowie 31 marca 1719 roku, ochrzczoną w Złotowie przez Aleksandra Działyńskiego ${ }^{10}$, kanonika gnieźnieńskiego w dniu 6 kwietnia 1719 roku ${ }^{11}$, zmarłą w Wojnowicach 19 sierpnia 1743 roku.

2 J. Pielas, Inwentarze pośmiertne ruchomości szlachty sandomierskiej z XVII-XVIII wieku - perspektywy i problemy metodologiczne przygotowywanej edycji źródłowej, w: Kwartalnik Historii Kultury Materialnej, t. 63, z. 4, wyd. Instytut Archeologii i Etnologii Polskiej Akademii Nauk, Warszawa 2015, s. 629-635.

3 Józef Działyński, syn Pawła i Magdaleny Leszczyńskiej, więcej zob.: A. Boniecki, Herbarz Polski, wyd. Gebethner i Wolff, t. V, Warszawa 1902, s. 160.

4 Marianna Katarzyna Potulicka córka Adama Wawrzyńca, starosty borzechowskiego i Małgorzaty Czapskiej - zob.: S. Uruski, Rodzina. Herbarz szlachty polskiej, wyd. Gebethner i Wolff, t. XIV, Warszawa 1917, s. 308.

5 Biblioteka Kórnicka Państwowej Akademii Nauk (dalej: BK PAN), rękopisy, sygn. BK 00613, k. 199.

6 BK PAN, rękopisy, sygn. BK 07235, k. 1 - odpis aktu chrztu dokonany przez Franciszka Popowskiego prepozyta kościelskiego z dnia 29 maja 1749 roku. BK PAN, sygn. 00613, k. 199 urodził się o godzinie dwunastej „w samo południe”.

7 BK PAN, sygn. BK 00613, k. 199. Urodził się o godzinie czwartej po południu.

8 Ib. K. 200v - ciało sprowadzone morzem i pochowane w kościele w Złotowie.

9 Ib. K. 199. Urodził się o godzinie ósmej po południu.

10 Aleksander Działyński (1693-1739), syn Pawła i Magdaleny Leszczyńskiej, brat Józefa, stryj dziecka. Więcej zob.: J. Korytkowski, Prałaci i Kanonicy Katedry Metropolitalnej Gnieźnieńskiej, od roku 1000 aż do dni naszych, t. I, wyd. Lange J. B., Gniezno 1883, s. 240-242. Po śmierci Aleksandra Działyńskiego został również sporządzony spis inwentarza - P.M. Dziembowski, Inwentarz rzeczy ruchomych po biskupie Aleksandrze Dziatyńskim z 1739 roku, w: GENS Rocznik towarzystwa Genealogiczno-Heraldycznego, Poznań 2018, s. 117-126.

11 Ib. k. 199v. Urodziła się „o godzinie ósmej z rana”. 
Od 1737/38 była żoną Wiktora Raczyńskiego, urodzonego przed 1698 rokiem, zmarłego ok. roku $1765^{12}$,

- Teresę Urszulę, urodzoną w Złotowie 20 października 1720 roku $^{13}$, siostra zakonna - chórowa u Benedyktynek Sakramentek w Warszawie, zmarła 14 stycznia 1756 roku $^{14}$,

- Annę Barbarę, urodzoną w Złotowie 16 lutego 1722 roku, zmarłą w Złotowie 17 maja 1723 roku $^{15}$.

Augustyn wcześnie stracił rodziców, matka Marianna zmarła w Złotowie 19 sierpnia $1730 \mathrm{roku}^{16}$, natomiast ojciec Józef zmarł 27 listopada $1735 \mathrm{roku}^{17}$.

Już jako młody człowiek Augustyn próbował się włączyć w życie polityczne i gospodarcze kraju, starał się podnieść znaczenie swojej gałęzi rodu. Odbierany był przez współczesnych jako „światły i rozumny obywatel”" ${ }^{18}$. W dość młodym wieku - mając 21 lat, został starostą nakielskim, nominację na to stanowisko otrzymał 27 kwietnia 1736 roku $^{19}$, a 30 czerwca 1736 roku zgodę na jurysdyk$\mathrm{cję}^{20}, \mathrm{~W}$ dniu 28 lutego 1739 roku otrzymał konsens królewski na przekazanie starostwa nakielskiego innemu Działyńskiemu ${ }^{21}$ [bratu Marcinowi]. Przekazanie to miało miejsce w 1742 roku $^{22}$. Po przekazaniu starostwa nakielskiego został

12 Więcej zob. P. M. Dziembowski, Inwentarz rzeczy ruchomych po Magdalenie z Działyńskich Raczyńskiej z 1743 roku, w: GENS Rocznik towarzystwa Genealogiczno-Heraldycznego, Poznań 2019, s. 147-154.

13 KB PAN, sygn. BK 00613, k. 199v. Jej chrzestnymi - chrztu na zamku w Złotowie udzielił Stanisław Marciński, byli: Stefan Łochocki, kasztelan rypiński i Konstancja z Ulatowskich Rydzyńska [córka Stanisława i Joanny Mielcyanówny, 1 v. Stefan Przybyszewski, 2 v. Mikołaj Rydzyński]. Urodziła się „o godzinie szóstej z rana”.

14 S. Małgorzata Borkowska OSB, Leksykon zakonnic polskich epoki przedrozbiorowej, t. 2, Polska Centralna i Poludniowa, wydawnictwo DiG, Warszawa 2005, s. 87. Imię zakonne - Maria Brygida od Męki Pańskiej.

15 KB PAN, sygn. BK 00613, k. 199v. Jej chrzestnymi byli: brat Augustyn i siostra Magdalena. Pochowana została w kościele złotowskim. Urodziła się „w pół do dziesiątej z rana”.

16 Ib. K. 200. Marianna została pochowana w kościele w Złotowie 4 września 1730 roku, natomiast jej pogrzeb miał miejsce 11 grudnia 1730 roku. Zmarła „trzy kwadranse na godzinę dziesiątą w noc".

17 Ib. K. 200. Pochowany został w kościele w Złotowie. Zmarł o wpół do ósmej z rana.

18 Więcej o Augustynie Działyńskim zob. biogram - W. Konopczyński, Działyński Augustyn h. Ogończyk (1717-1759), w: Polski Stownik Biograficzny, Polska Akademia Umiejętności, Kraków 1948, t. VI, s. 79-79.

19 Archiwum Główne Akt Dawnych w Warszawie (dalej: AGAD), Metryka Koronna, Księgi Pieczętne - Sigillata (dalej: MKKP), sygn. 25, s. 15 - zapis dotyczy konsensusu na odstąpienie starostwa przez Wojciecha Bnińskiego Augustynowi Działyńskiemu.

20 Ib. - zezwolenie (konsens) dla Wojciecha Bnińskiego na scedowanie starostwa nakielskiego wraz z jurysdykcją.

${ }^{21}$ AGAD, MKKP, sygn. 25, s. 89. Tutaj bez podania imion - „Działyński Działyńskiemu”.

22 Teki Dworzaczka, Materiaty historyczno-genealogiczne do dziejów szlachty wielkopolskiej XV-XX wieku. Biblioteka Kórnicka (dalej: TD), Grodzkie Nakło nr 206, zapis 6916, w: http://teki. bkpan.poznan.pl/ (10.06.2021) - ,jurysdykcja Augusta Działyńskiego kończy się w środę po 
podkomorzym wschowskim - nominacja 21 maja 1742 roku $^{23}$, a w 1750 roku wojewodą kaliskim - nominacja 29 sierpnia 1750 roku $^{24}$.

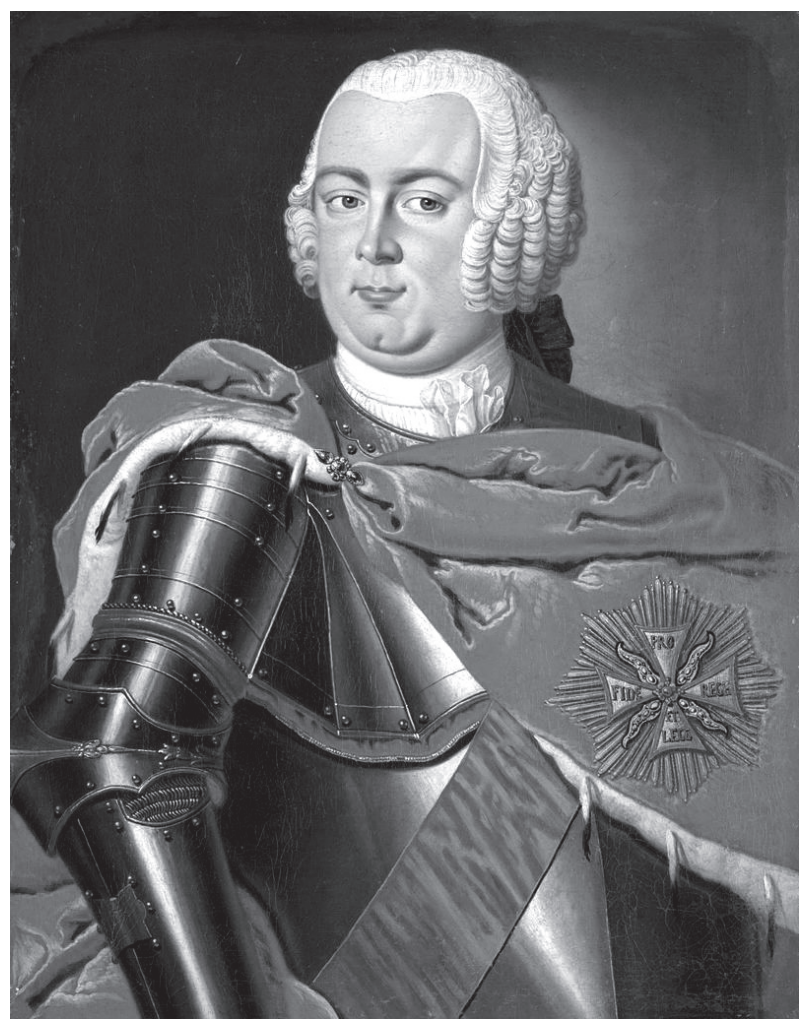

Portret Augusta Działyńskiego - olej na płótnie ${ }^{25}$

święcie Trinitatis [pierwsza niedziela po Zielonych Świątkach, środa wypadała w 1742 roku 23 maja], a w poniedziałek po św. Jakubie [30 lipca] rozpoczyna się jurysdykcja Marcina Działyńskiego".

23 AGAD, MKKP, sygn. 26, k. 141v.;Urzędnicy wielkopolscy XVI-XVIII wieku. Spisy, opr. A. Bieniaszewski, Wydawnictwo Polskiej Akademii Nauk, Zakład Narodowy im. Ossolińskich, Wrocław-Waszawa-Kraków-Gdańsk-Lódź 1987, zapis 1287 - tutaj podana również data wyboru -22 luty 1742 rok.

24 AGAD, MKKP, sygn. 27, s. 191, 192. W „Kuryerze Polskim” nr 727, podano datę nominacji 26 sierpnia 1750 roku.

25 Portret udostępniony za zgodą PAN Biblioteki Kórnickiej, będący w jej zbiorach - sygn. MK 3403. Obraz na płótnie, sporządzony ok. 1753 roku, o wymiarach 79x59,5. 


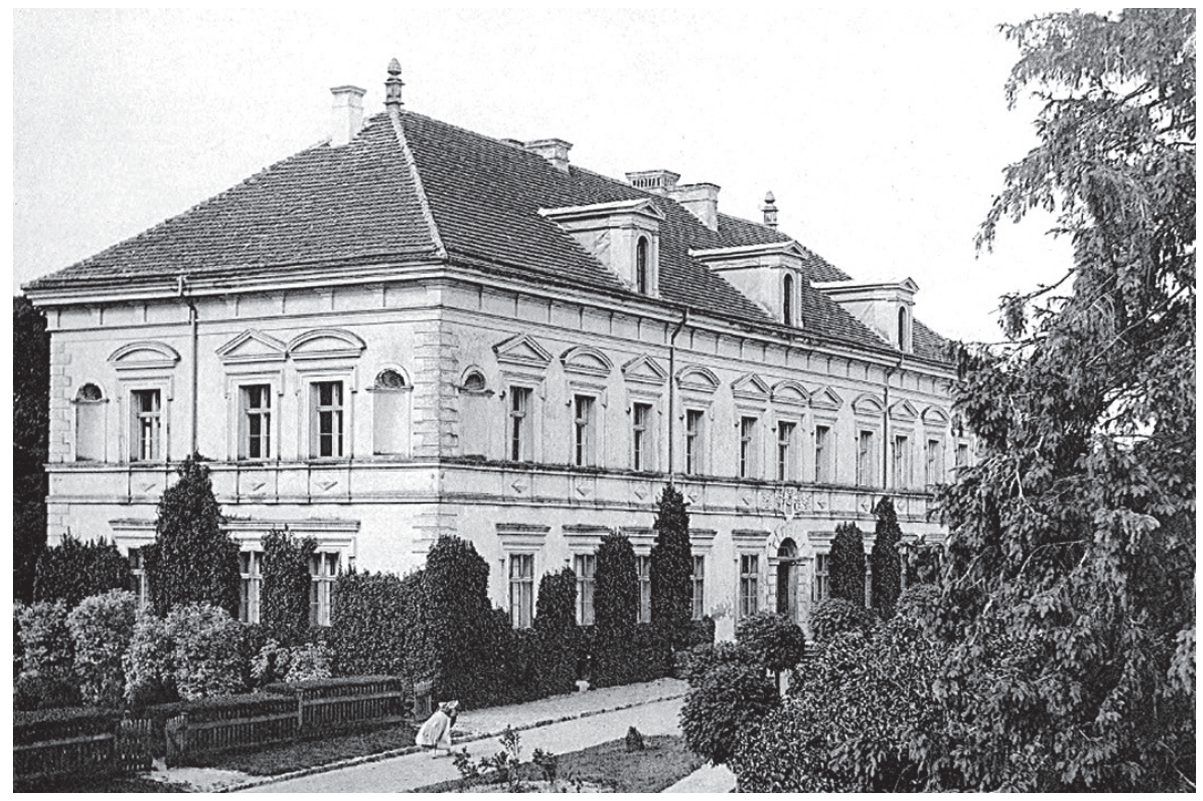

Zdjęcie pałacu z początku XX w. - fot. ze zbiorów p. E. Tomkowiaka z Dopiewa

W dniu 1 października 1737 roku w Konarzewie ${ }^{26}$ pojął za żonę Annę Radomicką, córkę Jana Antoniego (+1728), starosty generalnego Wielkopolski i dziedziczkę wraz z siostrą Franciszką, żoną Władysława Szołdrskiego, wojewody inowrocławskiego, dużej fortuny. W wyniku tego małżeństwa na drodze spadkowej sióstr Radomickich i jako wiano otrzymał pałac w Konarzewie wzniesiony w latach 90. XVII wieku przez ich dziada Andrzeja Aleksandra Radomickiego, wojewodę poznańskiego.

Małżeństwo Augustyna i Anny doczekało się 14 dzieci, byli to:

- Marianna Weronika, ochrzczona w Konarzewie 15 października 1740 roku²7, zmarła w dzieciństwie ${ }^{28}$,

26 Archiwum Archidiecezjalne w Poznaniu (dalej: AAP), księga ślubów - Liber Copulatorum (dalej: LC) parafii Konarzewo, sygn. PM 130/01, s. 102. Świadkowie: Maciej Mycielski, kasztelan poznański, Ludwig Szołdrski, wojewoda inowrocławski, Władysław Szołdrski, kasztelan łęczycki i Ludwik Chłapowski, podczaszy poznański.

27 AAP, księga chrztów - Liber Baptisatorum (dalej: LB) parafii Konarzewo, sygn. PM 130/01, s. 32. Chrztu udzielił ks. Kazimierz Józef Misiołowski, proboszcz konarzewski. Chrzestnymi byli: Stanisław Bogucki i Barbara Kurzeńska.

28 Brak ksiąg zgonów parafii Konarzewo za okres: październik 1737 - sierpień 1751, nie pozwala na określenie daty zgonu. 
- Franciszek Ksawery Jan Nepomucen, ochrzczony w Konarzewie 27 października $1741 \mathrm{roku}^{29}$, zmarł w dzieciństwie ${ }^{30}$,

- Dorota Józefa, ochrzczona w Konarzewie 12 kwietnia 1743 roku $^{31}$, zmarła w Konarzewie 12 marca 1763 roku $^{32}$, pochowana w Pakości 26 kwietnia 1763 roku $^{33}$. Ślub 6 lutego 1760 roku w Konarzewie z Franciszkiem Czapskim, podkomorzym chełmińskim, urodzonym ok. 1742 roku, zmarłym w Warszawie 9(11) kwietnia 1802 roku $^{34}$,

- Nepomucen Neriusz Stanisław, ochrzczony w Konarzewie 12 maja 1744 roku ${ }^{35}$, zmarł w dzieciństwie ${ }^{36}$,

- Mateusz Ignacy Józef, ochrzczony w Konarzewie 10 września 1745 roku ${ }^{37}$, zmarł w dzieciństwie ${ }^{38}$,

29 AAP, LB parafii Konarzewo, sygn. PM 130/01, s. 34. Chrztu udzielił ks. Szymon Ursiński, kanonik poznański. Chrzestnymi byli: Stanisław Bogucki, Marianna Strachowska, Chłapowski [Ludwik], pisarz ziemski w Poznaniu i Kwilecki [Łukasz], kasztelan lądzki.

30 Przy zgonie Magdaleny Estery w 1752 roku podano, że pochowana przy braciach. Brak ksiąg zgonów parafii Konarzewo za okres: październik 1737 - sierpień 1751, nie pozwala na określenie daty zgonu.

31 AAP, LB parafii Konarzewo, sygn. 130/01, s. 38. Chrztu udzielił Kazimierz Józef Misiołowski. Chrzestnymi byli: Wiktoria Brudzewska i Jan Kaszylski (Kuszewski?).

32 AAP, LM parafii Konarzewo, sygn. PM 130/01, s. 33.

33 AAG, LM parafii Pakość, zespól nr 0181, sygn. AP 157/15, s. 112v.

34 AAP, LC parafii Konarzewo, sygn. PM 130/01, s. 108, 110. Świadkowie: Dorota Jabłonowska, wdowa, wojewodzina rawska [babka panny młodej], Czapski, wojewoda chełmiński i Jabłonowski [Antoni Barnaba - brat przyrodni matki panny młodej Anny Działyńskiej z Radomickich], kasztelan międzyrzecki; A. Mańkowski, Czapski Franciszek Stanisław Kostka h. Leliwa (+ 1802), w: Polski Słownik Biograficzny, Polska Akademia Umiejętności, Kraków 1938, t. IV, s. 183, 184 - tutaj data zgonu 9 kwietnia.; w aktach parafii św. Krzyża w Warszawie, podana data zgonu 11 kwietnia 1802 rok i wiek 60 lat, przyczyna śmierci - paraliż, zob.: Internet strona genealodzy. pl, https://metryki.genealodzy.pl/metryka.php?ar=9\&zs=9243d\&sy=516\&kt=1\&plik=006. jpg\#zoom $=1 \& \mathrm{x}=1998 \& \mathrm{y}=530$.

35 AAP, LB parafii Konarzewo, sygn. PM 130/01, s. 40. Chrztu udzielił Kazimierz Józef Misiołowski; chrzestnymi byli: Stanisław Bogucki i panna Wiktoria Brudze(w)ska.

36 Przy zgonie Magdaleny Estery w 1752 roku, podano, że pochowana przy braciach. Brak ksiąg zgonów parafii Konarzewo za okres: październik 1737 - sierpień 1751, nie pozwala na określenie daty zgonu.

37 AAP, LB parafii Konarzewo, sygn. PM 130/01, s. 42. Chrztu udzielił ksiądz Krzysztof Otto. Chrzestnymi byli: Stanisław Bogucki i Wiktoria Brudze(w)ska.

38 Przy zgonie Magdaleny Estery w 1752 roku, podano, że pochowana przy braciach. Brak ksiąg zgonów parafii Konarzewo za okres: październik 1737 - sierpień 1751, nie pozwala na określenie daty zgonu. 
- Brygida Jadwiga Teresa, ochrzczona w Konarzewie 8 października 1746 roku ${ }^{39}$, zmarła w Konarzewie 10 września 1762 roku $^{40}$, była żoną Michała Czapskiego ostatniego wojewody malborskiego ${ }^{41}$, urodzonego ok. września 1723 roku, zmarłego w Koniecpolu 25 grudnia 1796 roku $^{42}$,

- Franciszek Kosma Damian Józef Walenty, ochrzczony w Konarzewie 8 października 1747 roku $^{43}$, zmarł w dzieciństwie ${ }^{44}$,

- Nepomucena Franciszka, ochrzczona w Konarzewie 15 kwietnia 1749 roku ${ }^{45}$, zmarła poza granicami Polski 30 czerwca 1779 roku $^{46}$. Ślub w Konarzewie 19 lutego 1764 roku z Teodorem Koźmińskim, wojewodzicem kaliskim ${ }^{47}$, urodzonym 9 października 1732 roku, zmarłym w Swarzędzu 16 kwietnia 1778 $\mathrm{roku}^{48}$,

- Magdalena Estera, ochrzczona w Konarzewie 15 lipca 1750 roku $^{49}$, zmarła w Konarzewie w styczniu 1752 roku $^{50}$,

39 AAP, LB parafii Konarzewo, sygn. PM 130/01, s. 45. Chrztu udzielił Kazimierz Józef Misiołowski. Chrzestnymi byli: Marcin i Helena - ubodzy (pauperes) w asystencji Antoniego Wrońskiego i Wiktorii Brudzewskiej.

40 AAP, Księga zmarłych - Liber Mortuorum (dalej: LM) parafii Konarzewo, sygn. PM 130/01, s. 31, 32. Pochowana w Pakości 30 września - Archiwum Archidiecezjalne w Gnieźnie, LM parafii Pakość, zespół nr 0181, sygn. AP 157/15, s. 111.

${ }^{41}$ A. Mańkowski, Czapski Michat (ur. 1702), w: Polski Stownik Biograficzny, Polska Akademia Umiejętności, Kraków 1938, t. IV, s. 191, 192.

42 Archiwum Diecezjalne w Kielcach, księga zgonów parafii Koniecpol 1764-1799, sygn. 412, s. 309 (319). Zmarł w wieku 73 lat, 2 miesięcy i 5 tygodni, pogrzeb 29 grudnia 1796 roku.

43 AAP, LB parafii Konarzewo, sygn. PM 130/01, s. 47. Chrztu udzielił ks. Krzysztof Otto. Chrzestnymi byli: Wiktoria Brudzewska i ojciec Krzysztof Ottto.

44 Przy zgonie Magdaleny Estery w 1752 roku podano, że pochowana przy braciach. Brak ksiąg zgonów parafii Konarzewo za okres: październik 1737 - sierpień 1751, nie pozwala na określenie daty zgonu.

45 AAP, LB parafii Konarzewo, sygn. PM 130/01, s. 50. Chrztu udzielił ks. Kazimierz Józef Misiołowski. Chrzestnymi byli: Marcin Obrajek i Jadwika Czechniaczka (nie szlachta).

46 AAP, LM parafii Swarzędz, sygn. PM 291/01, s. 223. Zapis dotyczy pogrzebu, który miał miejsce 17 lutego 1789 roku, zgodnie z wolą zmarłej, podano również datę miesięczną zgonu.

47 AAP, LC parafii Konarzewo, sygn. PM 130/01, s. 114.

48 AAP, LB parafii Swarzędz, sygn. PM 291/01, s. 194. Tutaj też podana data urodzenia. Pochowany 30 kwietnia 1778 roku.

49 AAP, LB parafii Konarzewo, sygn. PM 130/01, s. 52. Chrztu udzielił Łukasz Głowicki, prepozyt stęszewski. Chrzestnymi byli: Franciszek Skurzewski, oberleutnant z Poznania i Wiridiana z Bnińskich Raczyńska, kasztelanowa santocka [żona Leona Raczyńskiego].

50 AAP, LM parafii Konarzewo, sygn. PM 130/01, s. 22 - bez podania wieku i daty dziennej. Informacja, że pochowana przy swoich braciach. 
- Marianna Katarzyna, ochrzczona w Konarzewie 14 listopada 1751 roku $^{51}$, była żoną Justyniana Hilzena, generała majora wojsk litewskich i starosty marienhauskiego ${ }^{52}$, zmarłego w Dagdach na Litwie 27 września 1778 roku $^{53}$,

- Barbara Teofila, ochrzczona w Konarzewie 27 października 1752 roku $^{54}$, zmarła w Konarzewie 12 listopada 1752 roku $^{55}$,

- Józef Franciszek Ignacy Adam, ochrzczony w Konarzewie 15 września 1754 roku ${ }^{56}$, szef X regimentu pieszego wojsk koronnych, zmarł w Żytomierzu w listopadzie 1797 roku ${ }^{57}$. Ślub ok 1783 roku ze Szczęsną Woroniczówną ${ }^{58}$, urodzoną ok 1770, zmarłą $1831^{59}$,

- Stanisław Kostka Jerzy Jan Nepomucen Józef z Tolentino, ochrzczony w Konarzewie 1 listopada 1755 roku $^{60}$, zmarł w Konarzewie 24 kwietnia 1756 roku $^{61}$,

- Szymon Tadeusz Ksawery Piotr de Alcantary Walenty Rafael, urodzony w Konarzewie 24 października 1756 roku ${ }^{62}$, ochrzczony w Konarzewie 29 października 1756 roku $^{63}$, senator-wojewoda Księstwa Warszawskiego i Królestwa

51 AAP, LB parafii Konarzewo, sygn. PM 130/01, s. 61. Chrztu udzielił Kazimierz Józef Misiołowski. Chrzestnymi byli: Antoni Jabłonowski z żoną i księżna Dorota Jabłonowska, wojewodzina rawska [Dorota z domu Bronisz, babka dziecka, matka Anny z Radomickich Działyńskiej, żona Stanisława Wincentego Jabłonowskiego].

52 A. Boniecki, Herbarz Polski, wyd. Gebethner i Wolff, t. VII, Warszawa 1904, s. 279.

53 Encyklopedia Powszechna, nakład i druk S. Orgelbrand, t. XII, Warszawa 1863, s. 385.

54 AAP, LB parafii Konarzewo, sygn. PM 130/01, s. 59. Chrztu udzielił ks. Kazimierz Józef Misiołowski. Chrzestnymi byli: Franciszek Bronisz, pisarz pyzdrski i Franciszka z Radomickich Szołdrska, wojewodzina inowrocławska [pop. Szołdrska, żona Władysława Szołdrskiego, siostra matki dziecka - Anny Działyńskiej z Radomickich].

55 AAP, LM parafii Konarzewo, sygn. PM 130/01, s. 23. Pochowana przy braciach.

56 AAP, LB parafii Konarzewo, sygn. PM 130/01, s. 63. Chrztu udzielił ks. Kazimierz Józef Misiołowski. Chrzestną była Ludwika Rzeszotarska.

57 Więcej zob.: S. Kieniewicz, Działyński Ignacy Józef Franciszek Adam (1754-1797) w: Polski Słownik Biograficzny, Polska Akademia Umiejętności, Kraków 1948, t. VI, s. 80.

58 K. Pułaski, Kronika polskich rodów szlacheckich Podola, Wołynia i Ukrainy, t. II, wyd. DiG, Warszawa 2004, s. 280.

59 Potocki S., Genealogia kórnickiej linii Działyńskich, w: Pamiętnik biblioteki Kórnickiej, wyd. Polska Akademia Nauk, Biblioteka Kórnicka, Kórnik 1976, z. 12, s. 264.

60 AAP, LB parafii Konarzewo, sygn. PM 130/01, s. 67. Chrztu udzielił ks. Kazimierz Józef Misiołowski. Chrzestnymi byli: Szymon Waber, kaznodzieja Societatis Jezu i Dorota Działyńska, wojewodzianka kaliska [siostra dziecka].

${ }^{61}$ AAP, LB parafii Konarzewo, sygn. PM 130/01, s. 24 - określony jako „dziecko” Augustyna Działyńskiego, bez podania imienia.

62 Więcej zob.: W. Dworzaczek, Działyński Ksawery Szymon Tadeusz (1756-1819), w: Polski Słownik Biograficzny, Polska Akademia Umiejętności, Kraków 1948, t. VI, s. 88-89.

${ }^{63}$ AAP, LB parafii Konarzewo, sygn. PM 130/01, s. 70. Chrztu udzielił ks. Szymon Waber z Societalis Jezu. Chrzestnymi byli: ojciec Otto, teolog i Brigida Działyńska [siostra dziecka]. 
Polskiego, zmarł w Konarzewie 13 marca 1819 roku $^{64}$. Ślub z Justyną Dzieduszycką, urodzoną w 1764 roku, zmarłą w Dreźnie 30 czerwca 1844 roku $^{65}$. Augustyn Działyński zmarł w Konarzewie 13 maja 1759 roku $^{66}$, jego ciało zostało przetransportowane w dniu 28 maja procesją przez Poznań do Pakości ${ }^{67}$ i tam pochowane u Reformatorów w dniu 31 maja 1759 roku $^{68}$. W dniu 18 września 1759 serce Augustyna Działyńskiego zostało złożone w kościele jezuitów w Poznaniu ${ }^{69}$. Po śmierci Augustyna, jego żona Anna z Radomickich wyszła powtórnie za mąż ok. 1767/1768 roku za Władysława Gurowskiego, marszałka nadwornego litewskiego ${ }^{70}$. Anna zmarła 17 maja 1812 roku w Pałacu Działyńskich w Poznaniu, pochowana w Konarzewie 20 maja 1812 roku $^{71}$.

${ }^{64}$ AAP, LM parafii Konarzewo, sygn. PM 130/06, s. 102, 103 (stara nr 84-85), nr aktu 13/1819. Zmarł w wieku 63 lat na ,zapalenie piersi”. Pochowany 17 marca 1819 roku. W. Dworzaczek, Dziatyński Ksawery Szymon Tadeusz (1756-1819) w: Polski Stownik Biograficzny, Polska Akademia Umiejętności, Kraków 1948, t. VI, s. 88-89. Tutaj data zgonu 13 marca 1819 roku.

65 AAP, LM parafii Konarzewo, sygn. PM 130/11, s. 6-7 (inna 12-13). Pochowana 15 lipca 1844 roku. Informacja, że zmarła w Dreźnie.

${ }_{66}$ AAP, LM parafii Konarzewo, sygn. PM 130/01, s. 29.

${ }^{67}$ Kroniki Staropolskie, Kronika Reformatorów Poznańskich, opr. Jacka Wiesiołowskiego, Salezego Bogumiła Tomczaka O[rdo] F[ratrum] M[inorum] i Grzegorza Antoniego Wiśniowskiego OFM, Wydawnictwo Miejskie, Poznań 2006, s. 164 - tutaj skrócony opis procesji.

68 AAG, LM parafii Pakość, zespół 0181, sygn. AP 157/15, s. 95. Tutaj informacja, że chorował na ból głowy i astmę. Ciało złożono do grobu 30 maja wieczorem, natomiast pogrzeb miał miejsce 1 czerwca. Opisanie uroczystości zob.; B. Roszkowski, Widok żałobny dwóch znakomitych pogrzebów, ś. P. Jaśnie Wielmożnego Pana Jegomości Pana Augustyna na Kościelcu y Działyniu Chrabi Działyńskiego, wojewody kaliskiego, kawalera Orderu Orła Białego, konwentu Pakoskiego Wielebnych OO. Reformatorów Fundatora y Syndyka Apostolskiego, w dziedzicznym fundacji swojej grobie Roku Pańskiego 1759, dnia 1. Czerwca pochowanego i przy godnej pamięci ojcu swoim roku pańskiego1762, dnia 30. Września pogrzebioney ś. P. wielmożnej pani Jejmości pani Brygitty z Działyńskich Czapski, wojewodziny malborskiey, starościny kościerzyńskiej. Drukarnia akademicka, Poznań 1762 (?).

69 Kronika Staropolska. Kronika Reformatorów Poznańskich, opr. Jacka Wiesiołowskiego, Salezego Bogumiła Tomczaka OFM i Grzegorza Antoniego Wiśniowskiego OFM, Wydawnictwo Miejskie, Poznań 2006, s. 164. Z tej okazji zostało wygłoszone przez księdza Józefa Płochockiego i wydane drukiem kazanie pogrzebowe.

70 Więcej zob.: W. Konopczyński, Gurowski Władysław Roch h. Wczele (ok. 1715-1790), w: Polski Stownik Biograficzny, Polska Akademia Nauk, Wrocław-Warszawa-Kraków 1960-1961, t. IX, s. 171-173.

71 TD, Metrykalia, zapis 51621 - księga metrykalna Kórnik, pochowana w Konarzewie 20 maja 1812 roku. 


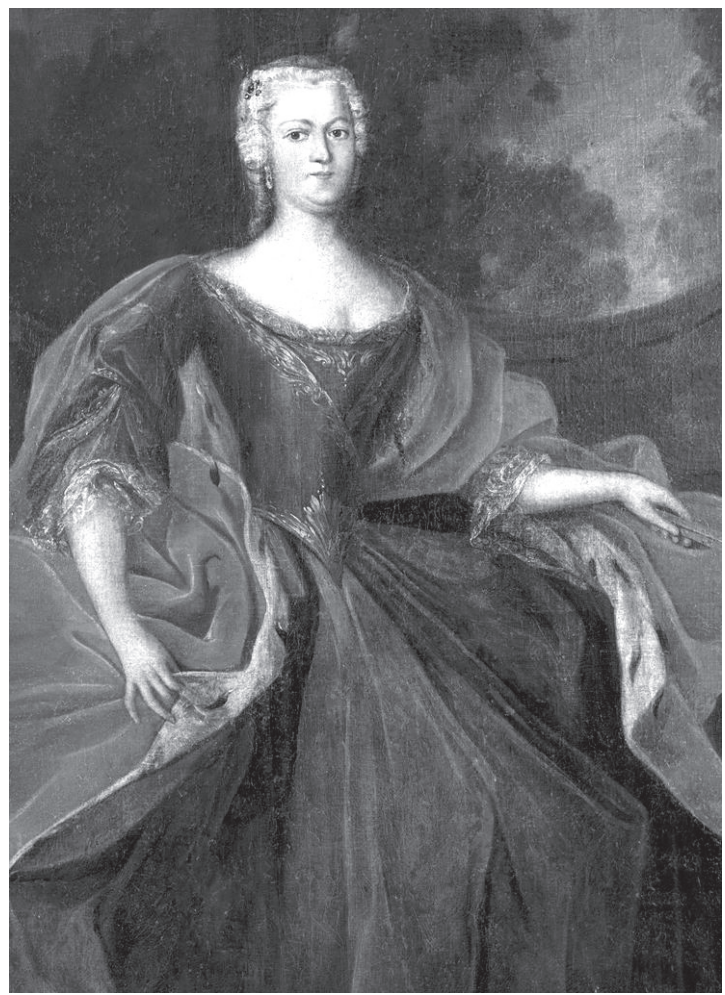

Portret Anny z Radomickich Działyńskiej - olej na płótnie ${ }^{72}$

Do naszych czasów nie zachowały się w kościele Konarzewskich żadne nagrobki czy też epitafia Działyńskich. Po przebudowie kościoła pod koniec lat 70. XVIII wieku przez Władysława Gurowskiego i jego żonę Annę z Radomickich Działyńskiej, szczątki jej dzieci zostały umieszczone w nowej krypcie ${ }^{73}$. W roku 1965 nastąpiła adaptacja krypty pod prezbiterium dla celów liturgicznych ${ }^{74} \mathrm{i}$ prawdopodobnie wówczas zostały usunięte ewentualne nagrobki i inskrypcje.

Jedyną rzeczą świadczącą o bytności Działyńskich w Konarzewie jest zachowana do czasów obecnych figura z piaskowca św. Jana Nepomucena z 1745 roku. Na cokole kartusz z widocznym herbem Ogończyk (Działyńskiego) i Kotwicz (Radomickiej).

72 Portret udostępniony za zgodą PAN Biblioteki Kórnickiej, będący w jej zbiorach - sygn. MK 3284. Obraz na płótnie, sporządzony ok. 1759 roku, o wymiarach 240x171.

73 Świadczą o tym zapisy przy aktach zgonów w księdze metrykalnej parafii Konarzewo.

74 Katalog zabytków sztuki w Polsce, Dawne województwo poznańskie, Dawny powiat poznański, pod red. T. Ruszczyńskiej i A. Sławskiej, t. V, z. 20, PAN, Instytut Sztuki, Warszawa 1977, s. 15. 


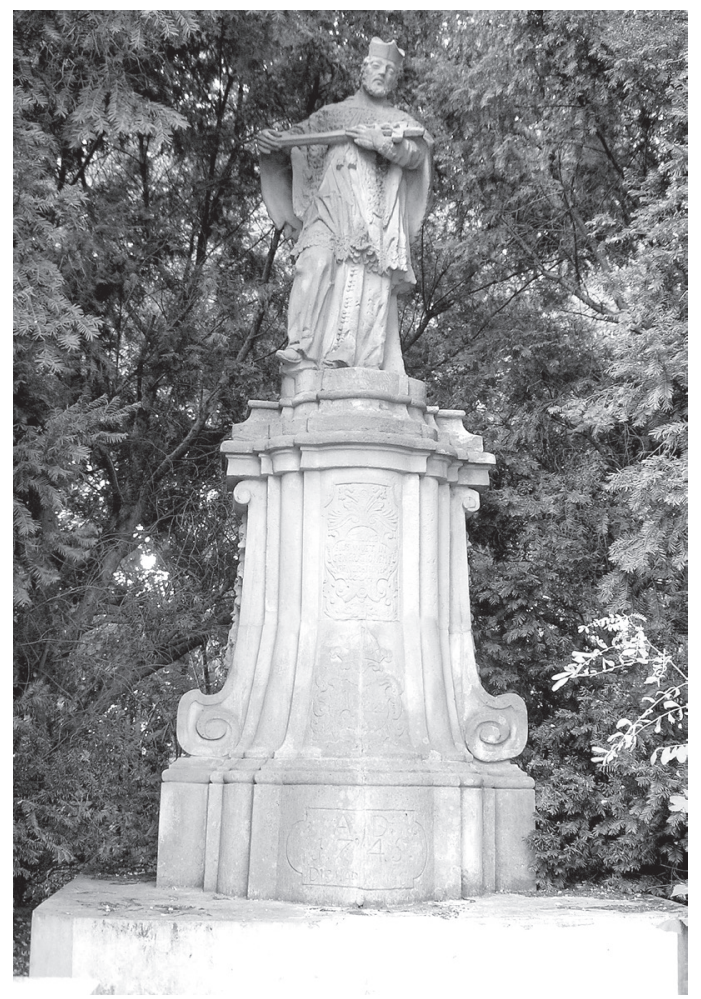

Figura św. Jana Nepomucena w Konarzewie - fot. archiwum autora

Przedmiotowy spis został najpierw sporządzony w brudnopisie - każda karta na końcu tekstu podpisana przez Annę Działyńską ${ }^{75}$. Na podstawie tego brudnopisu sporządzono oryginał ${ }^{76}$ już bez podpisu osoby spisującej. Spis zawiera rzeczy umieszczone w 17 skrzyniach. W skrzyni pierwszej znajdują się głównie siodła, uprząż końska, broń biała. W skrzyni drugiej, trzeciej, czwartej i siódmej - odzież noszona przez osobę zmarłą. W piątej, szóstej, ósmej i dwunastej - kilimy, kobierce, pawilony, kapelusze. W dziewiątej, dziesiątej i jedenastej - skóry, kotary, przykrycia. W trzynastej sprzęt do odprawiania mszy świętej, w czternastej instrumenty muzyczne i warcaby. W piętnastej armatki i moździerzyki mosiężne. W szesnastej lejce, katery, koce. W siedemnastej - skóry jelenie i odzież dla strzelców pańskich i służby, z elementami srebrnymi.

75 BK PAN, sygn. BK 07235, k. 3-6. Karta trzecia zapisana dwustronnie, karta czwarta zapisana jednostronnie i pół drugiej strony, karta piąta zapisane tylko pół strony, karta szósta zapisana jedna strona.

76 BK PAN, sygn. BK 07235, k. $14-17 \mathrm{v}$. Strona 14 to strona tytułowa, pozostałe strony zapisane dwustronnie. 
Najbliższy krąg rodzinny Augustyna Działyńskiego

\begin{tabular}{|c|c|c|c|c|c|}
\hline & \multicolumn{2}{|r|}{$\infty$ Marianna } & \multicolumn{2}{|c|}{$\begin{array}{l}\text { Józef } \\
\text { Katarzyna Potulicka }\end{array}$} & \\
\hline Г & $T$ & $T$ & T & $T$ & 7 \\
\hline Augustyn & Marcin & Adam & Magdalena & Teresa & Anna \\
\hline Jakub & Andrzej & Stanisław & Małgorzata & Urszula & Barbara \\
\hline * 28 VIII 1715 & * 14 XI 1716 & * $7 \mathrm{~V} 1718$ & * 31 III 1719 & * $20 \times 1720$ & * 16 II 1722 \\
\hline$\dagger 13 \mathrm{~V} 1759$ & $\dagger 15$ IX 1746 & $\dagger \quad 1718$ & $\dagger 19$ VIII 1743 & $\dagger 14$ I 1756 & $\dagger 17 \mathrm{~V} 1723$ \\
\hline$\infty 1 \times 1737$ & & & $\infty 1737 / 1738$ & & \\
\hline Anna & & & Wiktor & & \\
\hline Radomicka & & & Raczyński & & \\
\hline * 1724 & & & * przed 1698 & & \\
\hline$\dagger 17 \mathrm{~V} 1812$ & & & $\dagger$ ok. 1765 & & \\
\hline
\end{tabular}

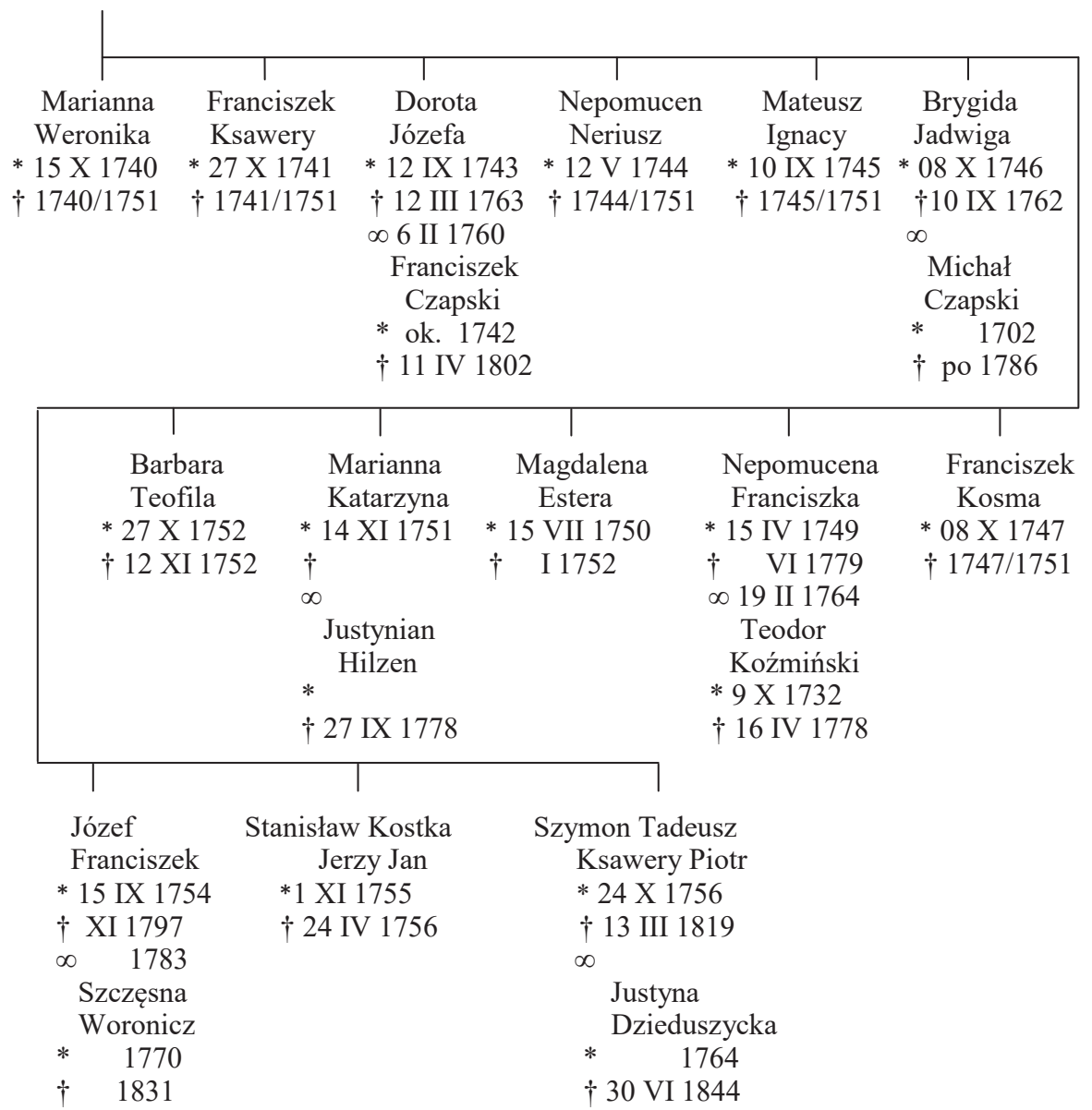


Na uwagę zasługuje bogate ozdobienie odzieży i sprzętu w złote lub srebrne elementy, świadczące o bogactwie ich posiadacza. Także broń biała: szabla, karabela, pałasz, kordelas są zdobione srebrem. Jest to typowy spis rzeczy „,codziennego" używania. Wiele rzeczy posiada wykończenia złotymi lub srebrnymi glonami lub są haftowane złotem lub srebrem. Ogółem opis podkreśla przynależność właściciela rzeczy do bogatej szlachty, magnaterii. W spisie nie ujęto pozostawionych przez zmarłego: gotowizny w złocie, srebrze, pieniądzach i klejnotów. Spora część rzeczy, jak wynika z opisu, jest pochodzenia tureckiego lub wzoru tureckiego, mogłoby to wskazywać na zainteresowanie Augustyna orientem, jego sztuką zdobniczą i pięknem. Jednakże są to prawdopodobnie pamiątki po jego pradziadzie Zygmuncie Działyńskim, wojewodzie kaliskim ${ }^{77}$, uczestniku wyprawy wiedeńskiej z $1683 \mathrm{roku}^{78}$.

W przedmiotowych aktach znajdują się również dokumenty, na które warto zwrócić uwagę. Pierwszy to spis pozostawionych przez zmarłego zobowiązań, nazwany „JW. Augustyn Działyński wojewoda kaliski obumierając zostawił długi niżej następujące". Ogólna ich kwota jest bardzo wysoka jak na ówczesne czasy i sięga prawie miliona złotych ${ }^{79}$. Działyński był winien:

- Mieczkowskiemu [Franciszkowi], kasztelanowi Konarskiemu- 80000 zł,

- Rynorzewskiemu - $30000 \mathrm{zł}$,

- Sulerzyckiemu - 30000 zt,

- Sakałaskiemu [Skałaskiemu] - $20000 \mathrm{zł,}$

- Wałeckiemu - $10000 \mathrm{zl}$,

- Cieńskiemu - 30000 zł,

- Markusowi - $3000 \mathrm{zł}$,

- Gostomskiemu [Andrzejowi Konradowi], podkomorzemu malborskiemu $50000 \mathrm{zł}$,

- Ostenowi - $38000 \mathrm{zl}$,

- Grotom - $15000 \mathrm{zl}$,

- Ulatowskiemu - $38000 \mathrm{zł}$,

- Gliszczyńskiej - 24000 zł,

- Guzoskiemu - 25000 zl,

- Gliszczyńskiemu [Maciejowi], pisarzowi kaliskiemu - 21000 zł,

- Kozłowskiemu 20000 zł,

- Chrościckiemu - 37000 zł,

- Jagniątkowskiemu - $21000 \mathrm{zk}$,

77 K. Piwarski, Działyński Zygmunt (+1685), w: Polski Słownik Biograficzny, Polska Akademia Umiejętności, Kraków 1948, t. VI, s. 99-100.

78 B. Twardowski, Spis Rycerstwa Polskiego walczacego z Janem III pod Wiedniem oraz Szyk bojowy Wojsk Polskich i sprzymierzonych dnia 12 września 1683 r., Nakładem Księgarni Katolickiej, Poznań 1883, s. 9.

79 BK PAN, sygn. BK 07235, k. 37. 
- Józefowi Kozłoskiemu - 9000 zł,

- Orgiewskim - 10000 zł,

- pannie Ossenownie - $18000 \mathrm{zl}$,

- Zbyszeskiemu - $15000 \mathrm{zl}$,

- Ośmiałowskiemu - $18000 \mathrm{zł}$,

- Boboleckiemu $32000 \mathrm{zł}$,

- Nasioroskiemu - $10800 \mathrm{zł}$,

- Jakubowi Łakińskiemu - 10000 zł,

- Wałdoskiemu - $36000 \mathrm{zl}$,

- Głuchnoskiemu - 1 299,2 zł,

- Raczyńskiemu - 333000 zł,

- kapitule gnieźnieńskiej - 19 196,08 zł

Razem : 963 295, 28 zł.

Wg dalszej adnotacji, wojewodzina kaliska (Anna Działyńska) spłaciła:

- Ulatowskiemu - $38000 \mathrm{zł}$,

- Skałaskiemu - $20000 \mathrm{zl}$,

- Zbyszewskiemu - $15000 \mathrm{zl}$,

- Gliszczyńskiemu, pisarzowi kaliskiemu - 21000 zł,

- Ostenównie, żonie Wiechlewskiego - 18000 zł.

Drugim wartym przejrzenia dokumentem są poniesione wydatki związane z pogrzebem Augustyna Działyńskiego ${ }^{80}$, a mianowicie:

- zakup produktów: cukru, ryżu, kaszy, rodzynek, migdałów, oliwy, pieprzu, imbiru, szafranu, goździków, gałek muszkatołowych, syropu, kaparów, cytryn i wina - suma 349 złotych,

- opłaty za dzwonienie w kościołach poznańskich: farze, tumie, u św. Wojciecha, św. Marcina w kwocie 72 tynfów,

- opłaty za msze u: Dominikanów, Karmelitów Bożego Ciała, Bernardynów, Franciszkanów, Karmelitów bosych, Reformatorów - razem 420 tynfów,

- opłaty za sukno na żałobę - 227 tynfów,

- za świece i pochodnie -414 złotych.

Trzecim dokumentem jest wykaz pozostawionych przez zmarłego księgozbioru $^{81}$. Spis ten został zatytułowany: Inwentarz ksiag Jaśnie W. J. P. Wojewody Kaliskiego pozostatych polskich jak i łacińskich, francuskich i manuskryptów do skrzyni sub litera A zamkniętych. W rejestrze tym występują słowniki, statuty, konstytucje, lauda wojewódzkie, książki z zakresu historii, i geografii, mapy i różne

\footnotetext{
80 BK PAN, sygn. 07235, k. 40, 41, 43, 44.

81 Ib., k. 24, 25.
} 
rękopisy. Księgi te stały się podstawą późniejszej Biblioteki Kórnickiej. Rejestr nie został opisany w artykule, gdyż temat ten został już poruszony w literaturze ${ }^{82}$.

\author{
ANEKS \\ Źródło: Biblioteka Kórnicka Państwowa Akademia Nauk, \\ rękopisy, sygn. BK 07235, k. $14-17 \mathrm{v}$.
}

Regestr albo konotacja rzeczy pozostatych po śmierci S.P.J.W. JMci Pana Augustyna Dziatyńskiego Wojewody Kaliskiego Roku 1759 D. 5 Juny.

$1{ }^{\text {mo }}$ w skrzyni pod literą A

Siodło zielone aksamitne mało co „zażywane” z frędzlą jedwabną zieloną Czaprak aksamitny

Pokrowce do olstrów takież

Rząd na jedwabnej taśmie cało obsadzany pozłocisty srebrny, ze wszystkim co należy na konia

Siatka zielona srebrem przerabiana

W tejże skrzyni:

Nadziak hebanowy w srebro oprawny

Trąbka myśliwska ze słoniowej kości w srebro oprawna

Trąbka myśliwska bawola w srebro oprawna

Trąbka myśliwska fiszbinowa w mosiądz oprawna

Karabela demeszkową ${ }^{83}$ robotą nabijana srebrem

Głownia turecka, tureckimi literami nabijana

Paski złotem przerabiane i w srebro oprawne

Pałasz staroświecki, kapturek srebrny i musztuczek ${ }^{84}$ srebrny

Szabla wyszynka ${ }^{85}$, rapcie $^{86}$ u niej jedwabne karmazynowe

Kordelas tombakowy przy którym łyżka i widelec tombakowy

Szpada u niej gifes ${ }^{87}$ srebrnym drutem obwijany

Szpady duże żałobne

Pałasz masztalerski w mosiądz oprawny

82 R. Marciniak, Księgozbiór Augustyna Działyńskiego (1715-1759), wojewody kaliskiego, w: Pamiętnik Biblioteki Kórnickiej, Kórnik 1976, z. 12, s. 191-235. Tutaj też zamieszczony wykaz książek.

83 Stal damasceńska - staropolski „demeszka”.

84 Musztuk - część uprzęży końskiej.

85 Nazwa szabli od miejsca jej wytwarzania - słynna wytwórnia szabel w Wyszynach w Wielkopolsce.

86 Rapcie - paski z taśmy albo sznurków do szabli.

87 Gifes - część rękojeści broni białej osłaniająca rękę; garda. 
Kordelas pazia w mosiądz oprawny

Laska fiszbinowa srebrem nabijana

Laska trzcinowa bez oprawy

Lufka z morskiej piany srebrem oprawna z cybuchem tureckim wpół składanym, oprócz tego cybuchy trzy tureckie

Róg kozacki do prochu w żelazo oprawny

Róg bawoli do prochu w mosiądz oprawny

Siodło czerwone aksamitne złotem haftowane z złotymi galonami

Czaprak złoty złotem haftowany

Frędzla jedwabna czerwona

Pokrowce od ostrów czerwone aksamitne złotem haftowane

Rząd czerwony jedwabny złotem przerabiany srebrno pozłocisty

Kulbaka polska staroświecka czerwona złotem i srebrem haftowana kule u niej obie duże w srebro oprawne, strzemiona mosiężne, tybinki ${ }^{88}$ stare, wojłok stary, skóra czerwona

Kulbaka czerwona aksamitna złotem haftowana oprawna w srebro kamieniami sadzona, strzemiona u niej husarskie mosiężne kamieniami jednakowymi sadzone. Do tej kulbaki wojłok i olstra stare. Dywdyk ${ }^{89}$ srebrem i złotem haftowany turecki na tle złotym i srebrnym.

Kaptury do ostrów czerwone aksamitne złotem haftowane $\mathrm{Jort}^{90}$ turecki aksamitny złotem haftowany. Nadto para ostrów na końcu aksamit zielony złotem haftowany

Cugle stare jedwabne karmazynowe

Siodło codzienne jelenią skórą oprawne. Na nim złoty galon w koło. Czaprak takiż i pokrowce na olstrach

W tejże skrzyni derka na konia czerwona pąsowa ze srebrnym galonem, herb haftowany

W tejże skrzyni pokrowców sztuk siedem na taborety włóczkową robotą, z tych dwa nie dokończone.

$2^{\text {do }} \mathrm{W}$ skrzyni pod literą B

Kiereja koloru słomianego aksamitna sobolami podszyta, u niej pętlice srebrne i potrzeby srebrne. Item kiereja zielona aksamitna złotym galonem obwiedziona pętlice mająca złote, marmurkami podszyta niecała jednak kawałki te które brakuje są w tej skrzyni. Sukien para wrzosowym aksamicie sobolami podszyte. Do tych sukien rękaw soboli luzem. Item rękawki z tureckiej materii sobolami obszyte. Item kiereja barankowa czarna karmazynowa kitajką podszyta bez jednego rękawa.

${ }_{88}$ Tybinka - część siodła, jego bok z poduszką kolanową.

89 Dywdyk - dawne określenie jedwabnej kapy na konia.

90 Jort (niem. Gurt) - pas do podtrzymywania siodła. 
Materii tureckiej sztuka jedna na kanapę złotem przerabiana. Druga sztuka na dwa wezgłowia do tej kanapy. Item suknia czerwona karmazynowa nowa wilkami podszyta, u niej guziki stalowe

$3^{\text {tio }}$ w skrzyni sub litera C

Suknia koloru perłowego, na niej garnitura francuska srebrna do tej sukni kamizelka drojetowa czerwona, na niej taka sama garnitura srebrna. Spodnie sukienne perłowe. Item suknia perłowa z czarnymi pętlicami, do tej sukni kamizelka drojetowa felpą ${ }^{91}$ czarną $\mathrm{w}$ szachownicę podszyta $\mathrm{z}$ czarną frędzlą. Spodnie popielate. Item suknia francuskiego sukna $\mathrm{w}$ jabłonkowym kolorze aksamitem czarnym podszyta, do niej kamizelka aksamitna czarna galonem złotem szamerowana felpą w szachownice podszyta, do tych sukien spodnie aksamitne czarne. Item sukien para z pąsowej angielskiej materii podszyta moskiewskimi kunami, guziki mosiężne pozłacane, spodnie z takiejże materii. Item suknia wierzchnia granatowa sukna francuskiego, złotym galonem szamerowana, u niej guziki pozłacane, do tej sukni kamizelka biała aksamitna galonem złotym szamerowana, spodnie sukienne granatowe. Item suknia aksamitna niebieska, gładko zrobiona, kamizelka takaż, spodnie takież. Item para sukien z francuskiego sukna zielonych, przechodzonych z poletami złotymi gładko zrobionych, do nich spodnie zielone. Item suknia pąsowa barankami podszyta z poletami złotymi. Kamizelka atłasowa biała z poletami złotymi, do tych sukien pludry pąsowe. Item kamizelka z materii złotolitej, fandeszpan ${ }^{92}$ złotolity. Item kamizelka z litej srebrnej materii, fundy szpan srebrny. Item kamizelka z litej srebrnej materii, fundyszpan u niej srebrny. Item suknia francuskiego sukna w szarym kolorze z poletami srebrnymi. Do niej kamizelka różowa galonem srebrnym szamerowana. Spodnie aksamitne stare czarne. Item para sukien czarnych z niestrzyżonego aksamitu. Item kamizelka czarne drojetowa. Item suknia karmazynowa czerwona z poletami srebrnymi bez guzików. Mankiety z srebrnej litej materii, spodnie aksamitne czerwone. Item suknia niebieska aksamitna bez fałdów, podszyta gronostajami. Item suknia pąsowa stara z poletami złotymi bez podszewki, do niej kamizelka atłasowa biała stara z poletami złotymi, spodnie stare czerwone. Item wilczura białych wilków atłasem karmazynowym podszyta. Item suknia loferska ${ }^{93}$ epoletami srebrnymi, fartuszek kitajkowy ${ }^{94}$, koronka srebrna, pas kitajkowy z frędzlą srebrną.

91 Felpa - rodzaj tkaniny kosmatej jedwabno-wełnianej lub aksamitu wełnianego.

92 Fundeszpan - zlepek dwóch wyrazów z języka niemieckiego, bez odpowiednika w języku polskim - Faden - nitka i spannen - naciągać, rozpinać, tu w znaczeniu przetykany/przeciągany złotą nitką.

93 Poprawnie laufer - giermek biegnący przed powozem lub orszakiem pańskim.

94 Kitajka - jedwab chiński. 
$4{ }^{\text {to }} \mathrm{W}$ skrzyni czwartej pod literą D

Suknia pąsowa kamlotu brukselskiego, galonem złotym szamerowana, u niej polety złote, guziki złote. Do tej sukni kamizelka morowa biała galonem złotym szamerowana, polety złote, guziki złote, spodnie jak suknia wierzchnia. Item suknia biała kamlotu brukselskiego, na niej fundy szpan złoty, guziki złote, do tej sukni kamizelka morowa czerwona, galonem złotym szamerowana, pludry z białego kamlotu. Item suknia kamlotowa popielata, u niej pętlice złote, guziki złote, do tej sukni kamizelka morowa biała $\mathrm{z}$ haftem złotym. Item suknia szara kamlotu brukselskiego, pętlice na niej srebrne, guziki srebrne, do tej sukni kamizelka z lamy srebrnej białej, spodnie jak suknia wierzchnia. Item suknia jedwabna kamlotu szarego stara na niej haft srebrny polety srebrne, guziki srebrne. Do tej sukni kamizelka białej mory haftowana srebrem, spodnie jak suknia wierzchnia. Item suknia gredytorowa $^{95}$ zielona stara z poletami złotymi, kamizelka takaż, spodnie takież. Item suknia $\mathrm{z}$ brukselskiego kamlotu w brzoskwiniowym kolorze, stara gładka robota. Item sukien para jedwabnych $\mathrm{z}$ materii barakoni ${ }^{96}$ popielatych, robota gładka starych, spodnie takież. Item surdut aksamitny felpą czarną podszyty, stary. Kamizelka drojetowa niebieska galonem srebrnym szamerowana. Item surdut popielaty brukselskiego kamlotu w koło jedwabiem haftowany bez podszewki. Item surdut norderowy ${ }^{97}$ biały z poletami srebrnymi stary. Item suknia moręgowata stara, kamizelka niebieska kamlotowa spodnie takież. Item kamizelka aksamitna niebieska stara ze złotym galonem. Item kamizelka karmazynowa stara, do tej kamizelki węgierka sukienna w zielonym kolorze podszyta marmurkami, galon do niej złoty z frędzlą złota. Spodnie atłasowe czarne. Item spodni starych kamlotowych czarnych dwoje. Item spodnie kamlotowe czerwone. Item szlafrok stary morowy popielicami podszyty. Item buty czarne sukienne, lisami podszyte.

\section{$5{ }^{\text {to }} \mathrm{W}$ skrzyni pod literą $\mathrm{E}$}

Kilimów czerwonych tureckich na ścianę sztuk cztery. Firanek w tym kolorze i materii do okien sztuk cztery. Kobierczyk fioletowy turecki haftowany złotem na stół jeden. Kobierczyk biały złotem haftowany, atłasem białym podszyty jeden. Kobierczyk turecki złotem przerabiany z frędzlą zieloną, złotem przerabianą jeden.

Kilimy tureckie złotem przerabiane stare na ścianę - trzy

Kobierczyk włóczkowy stary musułbasem ${ }^{98}$ podszyty - jeden

Brytów z aksamitu starego karmazynowego - siedem

Bryty z frędzlami starymi - dwa

\footnotetext{
95 Gredytura - ciężki jedwab francuski.

96 Barakan - rodzaj tkaniny wełnianej lub półwełnianej na osnowie jedwabnej.

97 Norder - grube sukno.

98 Musułbas - tkanina bawełniana turecka, używana do podszywania.
} 
Bryt na kanapę bez frędzli - jeden

Wał trypowy ${ }^{99}$ karmazynowy z kanapy - jeden

Powłoki adamaszkowe ze spodków - trzy

Pawilon adamaszkowy czerwony podróżny na około z galonkiem srebrnym - jeden Kołdra takaż z galonkiem i płatkiem takim na około łóżka do tej kołdry do ekronu ${ }^{100}$ zasłonka z galonkiem

Firanek adamaszkowych ze złotym galonkiem na około od kotary wielkiej - cztery Kołdra adamaszkowa do tych firanek $\mathrm{z}$ galonem złotym

Item firanek srebrnych adamaszkowych karmazynowych z galonem na około dwie

Kołdra bogata na białym atłasie złotym jedwabiem haftowana na łóżko wielkie jedna

Kobierzec aksamitny czerwony stary złotem i srebrem haftowany, atłasem żółtym podszyty - jeden

Pawilon adamaszkowy czerwony stary - jeden

Kobierczyk sukienny zielony jedwabną frędzlą, na przykrycie stołu - jeden

Kobierczyk sukienny granatowy, haftowany suknem żółtym. Przykrycia niebieskiego koloru adamaszkowe ze złotym galonkiem na krzesełka.

Kawałki materii tureckiej, starej od kanapy - dwa

Kołdra biała marslową ${ }^{101}$ robotą - jedna

Kapelusz, na którym złoty fandyszpan i pióro białe - jeden

Kapelusz ze srebrnym galonem - jeden

Kapelusz kosmaty zimowy - jeden

Kapelusz stary - jeden

Czapka barankowa siwa spuszczana - jedna

$6{ }^{\text {to }} \mathrm{W}$ skrzyni pod literą $\mathrm{F}$

Pawilon nowy adamaszkowy czerwony z galonem złotym na dwie osoby

Kołdra nowa adamaszkowa i płatek u nich, galon na około, zasłonka adamaszkowa na Ekron także z galonem złotym

$7^{\mathrm{mo}} \mathrm{w}$ skrzyni pod literą G

Kiereja barakonowa czerwona niedźwiadkami podszyta. Item płaszcz czerwony, listwy u niego aksamitem czarnym podszyte. Węgierka hajducza niedźwiadkami podszyta. Surduty stangreckie niedźwiadkami starymi podszyte - dwa. Poduszki aksamitne duże, jedna z frędzlą na około, druga goła

\footnotetext{
99 Poprawnie trypt - materia jedwabna.

100 Ekron - prawdopodobnie z j. francuskiego ekran - parawanik.

${ }^{101}$ Prawdopodobnie nazwa od miejscowości Le Mans (Francja), gdzie wyrabiano tkaniny wełniane.
} 
$8{ }^{\mathrm{vo}}$ W skrzyni pod literą $\mathrm{H}$

Obicia adamaszkowego niebieskiego brytów trzydzieści trzy. U góry galony złote i wężyk złoty, u dwóch galon złoty na około. Kilimek turecki stary w czerwonym i niebieskim kolorze - jeden. Pawilon adamaszkowy niebieski stary na około galonek srebrny. Obicia atłasowego w cienie, starego brytów dwadzieścia pięć, w kościele dwa. Kołpaków niedźwiedzich sześć, czerwonych cztery, na stangretów a dwa na hajduków.

$9{ }^{\text {no }} \mathrm{W}$ skrzyni pod literą $\mathrm{J}$

Niedźwiedzi białych dwa na około brzegu w sukno pąsowe, na tym suknie galon pojedynczy srebrny. Niedźwiedzia szara na konia, u niej w koło sukno granatowe bez galonu.

$10{ }^{\mathrm{mo}}$ we dwóch skrzyniach

Kotary dwie, wezgłowia dwa od kotary adamaszkowej.

$11^{\mathrm{mo}}$

Przykrycia na kolebkę adamaszkowe, galonem złotym obszyte. Item firanki do tejże kolebki adamaszkowe karmazynowe.

12 mo

Kobierce włóczkowe duże z herbami pańskimi na przykrywanie stołów - dwa. Item kobierzec jedwabny tejże wielkości bez herbu - jeden.

$13^{\text {tio }}$

Apparat kościelny ze wszystkim

Ampułki srebrne

Miedniczka srebrna auszpurską ${ }^{102}$ robotą

Kielich srebrny pozłocisty

Patena srebrna pozłocista

Mszał

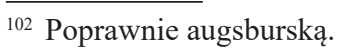


14 to

Skrzypce kremnickie ${ }^{103}$ - jedne

Oktawka hebanowa słoniową kością wysadzana - jedna

Fagot - jeden

Wiola ze smyczkiem hebanowym

Bandura - jedna

Arcabnica ${ }^{104}$ hebanem wysadzana i kością z arcabami ${ }^{105}$ takimi

Item arcabnica stara hebanem powleczona $\mathrm{z}$ arcabami

\section{$15^{\text {to }}$}

Armatek mosiężnych, żelazem oprawnych sztuk trzy

Moździerzyków mosiężnych sztuk cztery

\section{$16^{\text {to }}$}

Lejce kamelcharowe ${ }^{106}$ czerwone ze wszystkim co należy na cug koni jeden Item kamelcharowe żółte, we wszystkim co należy na cug koni Item kamelcharowe przerabiane niebieskie $\mathrm{z}$ białym

Szor do tych lejców srebrem pobielany

Kareta berlińska, żółtą trypą wybita

Item lejce jedwabne, złotem przerabiane w kolorze karmazynowym

Kareta aksamitem, frędzlą złotą i galonem złotym wybita

Koców włóczkowych z dubeltowymi orłami granatowym kolorem wyrobiona sztuk pięć

Koc szósty biały z frędzlą włóczkową, na przykrycie konia.

\section{$17^{\text {mo }}$}

Skóry jelenie wyprawne trzy

Srebra hajducze:

Pas przez ramię, na którym jest sztuk czterdzieści siedem, przy tym pasie blacha na której herb pański wybity. Przy blasze szabla w srebro oprawna i pochwy oprawne. Item pas drugi, na którym sztuk czterdzieści siedem, przy tym pasie blacha także z herbem pańskim przy blasze. Szabla w srebro oprawna, u niej dwa

\footnotetext{
${ }^{103}$ Nazwa od miejsca pochodzenia - Kremnica (Słowacja).

104 Arcabnica - warcabnica.

${ }^{105}$ Arcaby - warcaby.

${ }^{106}$ Poprawnie kamcharowe - rodzaj atłasu jedwabnego.
} 
kółka wyrwane, jednak na wstążce są przywiązane. Item magierki ${ }^{107} \mathrm{dwie}$ z tabliczkami srebrnymi, na których herby pańskie wybite, w koło nich galonki srebrne.

Srebro na strzelca:

Pas na ramię, na którym guzów pięćdziesiąt pięć, przy tym pasie sprzączek dużych cztery, sztyftów sześć. Item trąbka rogowa w srebro oprawna. Item pendent ${ }^{108}$ w koło guzami sadzony, tych guzów jest dwadzieścia osiem. Zamek srebrny, na nim herb pański wysztychowany, sprzączka mosiężna pobielana, kordelas w srebro oprawny. Item kordelas pański zielony tombakowy pozłocisty z parą noży, do tego kordelasa pendent zielony złotem przerabiany, zamek albo sprzączka srebrna, pozłocista, sadzona kamieniami zielonymi.

Laski loferskie trzcinowe dwie duże, na nich gałki srebrne, u dołu skuwki srebrne Laska pańska trzcinowa, na niej nadziak szczerozłoty, na dole skuwka szczerozłota Szpada pańska, u niej gifes ${ }^{109}$ szczerozłoty, munsztuczek, haczyk i skuwka szczerozłota

Item blachy dwie srebrne $\mathrm{z}$ herbami pańskimi od loferskich kabur.

Cyfry srebrne hajduckie dwadzieścia cztery, guzów srebrnych dwadzieścia cztery Item noży porcelanowych w srebro oprawnych sztuk dwanaście.

\section{Źródła rękopiśmienne}

Archiwum Główne Akt Dawnych w Warszawie:

- zespół: Metryka Koronna, Księgi Pieczętne - Sigillata,

- sygn. 1/4/0/3/S 25 ,

- sygn. $1 / 4 / 0 / 3 / \mathrm{S} 26$,

- sygn. 1/4/0/3/S 27.

Biblioteka Kórnicka Polskiej Akademii Nauk:

- zespół rękopisy,

- sygn. BK 00613,

- sygn. BK 07235.

Archiwum Archidiecezjalne w Gnieźnie:

- zespół 0181: księgi metrykalne parafii Pakość,

- sygn. AP 157/15.

\footnotetext{
${ }^{107}$ Magierka - czapka węgierska.

${ }^{108}$ Pendent - pas noszony przez ramię, służący do noszenia broni białej.

${ }^{109}$ Gifes - rękojeść.
} 
Archiwum Archidiecezjalne w Poznaniu:

- zespół: księgi metrykalne parafii Konarzewo,

- sygn. PM 130/01,

- sygn. PM 130/06,

- sygn. PM 130/11.

- zespół: księgi metrykalne parafii Swarzędz,

- sygn. PM 291/01.

Archiwum Diecezjalne w Kielcach

- zespół: księgi metrykalne parafii Koniecpol

- sygn. 412.

\section{Internet}

Teki Dworzaczka, Materiaty historyczno-genealogiczne do dziejów szlachty wielkopolskiej $X V-X X$ wieku. Biblioteka Kórnicka, http://teki.bkpan.poznan.pl (10.06.2021).

Genealodzy.pl, księgi metrykalne parafii św. Krzyża w Warszawie, https:// metryki.Genealodzy. pl/metryka.php?ar $=9 \& z \mathrm{zs}=9243 \mathrm{~d} \& \mathrm{sy}=516 \& \mathrm{kt}=1 \& \mathrm{plik}=006$. jpg\#zoom $=1 \& \mathrm{x}=1998 \& \mathrm{y}=530(10.06 .2021)$.

\section{Material ikonograficzny}

Portret Augustyna Działyńskiego, Państwowa Akademia Nauk, Biblioteka Kórnicka, sygn. MK 3403.

Portret Anny z Radomickich Działyńskiej, Państwowa Akademia Nauk, Biblioteka Kórnicka, sygn. MK 3284.

Zdjęcie pomnika św. Jana Nepomucena w Konarzewie - archiwum autora.

Zdjęcie pałacu w Konarzewie $-\mathrm{z}$ archiwum p. E. Tomkowiaka z Dopiewa.

\section{Bibliografia}

Boniecki A., Herbarz Polski, wyd. Gebethner i Wolff, t. V, Warszawa 1902. Boniecki A., Herbarz Polski, wyd. Gebethner i Wolff, t. VII, Warszawa 1904. Borkowska Małgorzata S[iostra] O[rdo] S[ancti] B[enedicti], Leksykon zakonnic polskich epoki przedrozbiorowej, t. II, Polska Centralna i Poludniowa, wydawnictwo DiG, Warszawa 2005. 
Dworzaczek W., Dziatyński Ksawery Szymon Tadeusz (1756-1819) w: Polski Słownik Biograficzny, Polska Akademia Umiejętności, Kraków 1948, t. VI.

Dziembowski P. M., Inwentarz rzeczy ruchomych po Magdalenie z Dziatyńskich Raczyńskiej z 1743 roku, w: GENS Rocznik Towarzystwa Genealogiczno-Heraldycznego, Poznań 2019.

Dziembowski P.M., Inwentarz rzeczy ruchomych po biskupie Aleksandrze Dziatyńskim z 1739 roku, w: GENS Rocznik Towarzystwa Genealogiczno-Heraldycznego, Poznań 2018.

Encyklopedia Powszechna, nakład i druk S. Orgelbrand, t. XII, Warszawa 1863.

Katalog zabytków sztuki w Polsce, Dawne województwo poznańskie, Dawny powiat poznański, pod red. T. Ruszczyńskiej i A. Sławskiej, t. V, z. 20, PAN, Instytut Sztuki, Warszawa 1977.

Kieniewicz S., Działyński Ignacy Józef Franciszek Adam (1754-1797) w: Polski Słownik Biograficzny, Polska Akademia Umiejętności, Kraków 1948, t. VI.

Konopczyński W., Gurowski Władysław Roch h. Wczele (ok. 1715-1790), w: Polski Słownik Biograficzny, Polska Akademia Nauk, Wrocław-WarszawaKraków 1960-1961, t. IX.

Konopczyński W., Działyński Augustyn h. Ogończyk (1717-1759), w: Polski Słownik Biograficzny, Polska Akademia Umiejętności, Kraków 1948, t. VI.

Korytkowski J., Prałaci i Kanonicy Katedry Metropolitalnej Gnieźnieńskiej, od roku 1000 aż do dni naszych, t. I, wyd. Lange J. B., Gniezno 1883.

Kroniki Staropolskie, Kronika Reformatorów Poznańskich, opr. Jacka Wiesiołowskiego, Salezego Bogumiła Tomczaka O[rdo] F[ratrum] M[inorum] i Grzegorza Antoniego Wiśniowskiego OFM, Wydawnictwo Miejskie, Poznań 2006.

„Kuryer Polski” nr 727 z 1750 roku.

Mańkowski A., Czapski Franciszek Stanisław Kostka h. Leliwa (+ 1802), w: Polski Słownik Biograficzny, Polska Akademia Umiejętności, Kraków 1938, t. IV.

Mańkowski A., Czapski Michał (ur. 1702), w: Polski Słownik Biograficzny, Polska Akademia Umiejętności, Kraków 1938, t. IV.

Marciniak R., Ksiegozbiór Augustyna Dziatyńskiego (1715-1759), wojewody kaliskiego, w: Pamiętnik Biblioteki Kórnickiej, wyd. Polska Akademia Nauk, Biblioteka Kórnicka, Kórnik 1976, z. 12.

Pielas J., Inwentarze pośmiertne ruchomości szlachty sandomierskiej z XVIIXVIII wieku - perspektywy i problemy metodologiczne przygotowywanej edycji źródłowej, w: Kwartalnik Historii Kultury Materialnej, t. 63, z. 4, wyd. Instytut Archeologii i Etnologii Polskiej Akademii Nauk, Warszawa 2015.

Pośpiech A., Pułapka oczywistości. Pośmiertne spisy ruchomości szlachty wielkopolskiej z XVII wieku, wyd. Letter Quality, Warszawa 1992.

Piwarski K., Działyński Zygmunt (+1685), w: Polski Słownik Biograficzny, Polska Akademia Umiejętności, Kraków 1948, t. VI. 
Potocki S., Genealogia kórnickiej linii Działyńskich, w: Pamiętnik Biblioteki Kórnickiej, wyd. Polska Akademia Nauk, Biblioteka Kórnicka, Kórnik 1976, z. 12.

Pułaski K., Kronika polskich rodów szlacheckich Podola, Wotynia i Ukrainy, t. II, wyd. DiG, Warszawa 2004.

Roszkowski B., Widok żałobny dwóch znakomitych pogrzebów, ś. P. Jaśnie Wielmożnego Pana Jegomości Pana Augustyna na Kościelcu y Dziatyniu Chrabi Dziatyńskiego, wojewody kaliskiego, kawalera Orderu Orta Biatego, konwentu Pakoskiego Wielebnych OO. Reformatorów Fundatora y Syndyka Apostolskiego, $w$ dziedzicznym fundacji swojej grobie Roku Pańskiego 1759, dnia 1. Czerwca pochowanego i przy godnej pamięci ojcu swoim roku pańskiego1762, dnia 30. Września pogrzebioney ś. P. wielmożnej pani Jejmości pani Brygitty z Dziatyńskich Czapskiej, wojewodziny malborskiey, starościny kościerzyńskiej. Drukarnia Akademicka, Poznań 1762 (?).

Twardowski B., Spis Rycerstwa Polskiego walczacego z Janem III. pod Wiedniem oraz Szyk bojowy Wojsk Polskich i sprzymierzonych dnia 12 września 1683 r., Nakładem Księgarni Katolickiej, Poznań 1883.

Uruski S., Rodzina. Herbarz szlachty polskiej, wyd. Gebethner i Wolff, t. XIV, Warszaw 1917.

Urzędnicy wielkopolscy XVI-XVIII wieku. Spisy, opr. A. Bieniaszewski, Wydawnictwo Polskiej Akademii Nauk, Zakład Narodowy im. Ossolińskich, WrocławWarszawa-Kraków-Gdańsk-Łódź 1987. 